Tersedia online di: http://ejournal-balitbang.kkp.go.id/index.php/jra

\title{
PENGARUH RANGSANGAN HORMON AROMATASE INHIBITOR DAN OODEV TERHADAP PERUBAHAN KELAMIN DAN PERKEMBANGAN GONAD IKAN KERAPU SUNU, Plectropomus leopardus
}

\author{
Hirmawan Tirta Yudha*\#, Agus Oman Sudrajat ${ }^{* *}$, dan Haryanti*) \\ *) Balai Besar Riset Budidaya Laut dan Penyuluhan Perikanan \\ *) Institut Pertanian Bogor
}

(Naskah diterima: 6 Desember 2017; Revisi final: 11 Januari 2018; Disetujui publikasi: 11 Januari 2018)

\begin{abstract}
ABSTRAK
Permasalahan utama yang dihadapi dalam penyediaan calon induk ikan kerapu sunu Plectropomus leopardus hasil budidaya yang bersifat hermaprodit sekuensial adalah keterlambatan dalam perkembangan gonad dan perubahan gonad dari betina menjadi jantan. Manipulasi hormonal merupakan cara yang paling efektif dan efisien dalam memacu perkembangan reproduksi dan pematangan gonad. Tujuan dari penelitian ini adalah untuk mendapatkan dosis hormon aromatase inhibitor dan oodev yang tepat untuk memacu perubahan kelamin dan perkembangan gonad ikan kerapu sunu. Ikan uji yang digunakan sebanyak 35 ekor F-1 dengan bobot rerata 2,3 $\pm 0,28 \mathrm{~kg}$. Penelitian dilakukan selama dua bulan. Induksi hormon dilakukan melalui penyuntikan setiap dua minggu sekali dengan empat dosis aromatase inhibitor dan oodev yang berbeda; A (aromatase inhibitor $1 \mathrm{mg} \mathrm{kg}^{-1}$ ikan), 0 (oodev $1 \mathrm{~mL} \mathrm{~kg}^{-1}$ ikan), A01 (aromatase inhibitor 0,1 mg kg-1 $\mathrm{k}$ an + oodev $1 \mathrm{~mL} \mathrm{~kg}^{-1} \mathrm{ikan}$ ), AO2 (aromatase inhibitor $1 \mathrm{mg} \mathrm{kg}^{-1} \mathrm{ikan}+$ oodev $1 \mathrm{~mL}$ $\mathrm{kg}^{-1} \mathrm{ikan}$ ), dan $\mathrm{K}$ (plasebo). Hasil penelitian menunjukkan bahwa kombinasi aromatase inhibitor $1 \mathrm{mg} \mathrm{kg}^{-1}$ ikan dan oodev $1 \mathrm{~mL} \mathrm{~kg}{ }^{-1}$ ikan efektif untuk merangsang perubahan kelamin. Perlakuan tersebut dapat meningkatkan konsentrasi testosteron dalam darah $(2,819 \mathrm{ng} / \mathrm{mL})$ setelah delapan minggu pemeliharaan. Berdasarkan hasil histologi gonad dan observasi terhadap ekspresi gen terkait reproduksi menggunakan gen target DMRT1 dan SOX3 menunjukkan bahwa perlakuan hormon AO2 (Aromatase inhibitor $1 \mathrm{mg}$ $\mathrm{kg}^{-1} \mathrm{ikan}+$ oodev $1 \mathrm{~mL} \mathrm{~kg}^{-1} \mathrm{ikan}$ ) terbukti dapat memacu perubahan kelamin dari betina menjadi jantan dan kematangan gonad pada ikan kerapu sunu Plectropomus leopardus.
\end{abstract}

KATA KUNCl: aromatase inhibitor; jantan; kerapu sunu; manipulasi hormonal; oodev

ABSTRACT: The effects of hormone aromatase inhibitor and oodev induction on sex reversal and gonadal development of coral trout grouper (Plectropomus leopardus). By: Hirmawan Tirta Yudha, Agus Oman Sudrajat, and Haryanti

The main problems faced in providing prospective broodstock of protogynous hermaphrodite coral trout grouper Plectropomus leopardus are lateness of gonadal development and gonadal sex reversal from femaleto male. Hormonal manipulation is the most effective way to induce reproductive development and gonadal maturation. The present study aimed to determine an effective dose of aromatase inhibitor and oodev on sex reversal and gonadal development of coral trout grouper. There were $35 \mathrm{~F}-1$ fish with an average weight of $2.3 \pm 0.28 \mathrm{~kg}$. This research was conducted for two months. The fish were injected with four different dosages of aromatase inhibitor and oodev every two weeks: A (aromatase inhibitor $1 \mathrm{mg} \mathrm{kg}-1 \mathrm{fish}$ ), 0 (1 mL oodev), A01 (aromatase inhibitor $0.1 \mathrm{mg} \mathrm{kg}-1$ fish + oodev $1 \mathrm{~mL} \mathrm{~kg}$ 1 fish), A02 (aromatase inhibitor $1 \mathrm{mg} \mathrm{kg}-1$ fish + oodev $1 \mathrm{~mL} \mathrm{~kg}-1$ fish), and $\mathrm{K}$ (placebo). The results showed that the combination of aromatase inhibitor $1 \mathrm{mg} \mathrm{kg}-1$ fish and oodev $1 \mathrm{~mL} \mathrm{~kg}-1$ fish was effective to induce the sex change. It could increase the concentration of testosterone in the blood $(2.819 \mathrm{ng} / \mathrm{mL})$ after eight weeks of culture. Based on the results of gonadal histology and reproductive-related genes expression observations using DMRT1 and SOX3 target genes, the hormonal treatment of AO2 (aromatase inhibitor $1 \mathrm{mg} \mathrm{kg}-1$ fish + oodev $1 \mathrm{~mL} \mathrm{kg-1} \mathrm{fish)} \mathrm{was} \mathrm{able}$ to accelerate sex reversal from female to male and gonadal maturation in coral trout grouper Plectropomus leopardus.

KEYWORDS: aromatase inhibitor; coral trout grouper; hormonal manipulation; male; oodev

\footnotetext{
\# Korespondensi: Balai Besar Riset Budidaya Laut dan

Penyuluhan Perikanan. Jl. Br. Gondol Kec. Gerokgak Kab.

Buleleng, Po. Box 140, Singaraja 81155, Bali, Indonesia.

Tel. + 6236292272

E-mail: info.gondol@gmail.com
} 


\section{PENDAHULUAN}

Ikan kerapu merupakan salah satu komoditas perikanan laut yang sangat potensial untuk dikembangkan. Berdasarkan data Badan Pusat Statistik pada tahun 2013 ekspor ikan kerapu dalam keadaan hidup mencapai 2.552 ton dengan nilai USD 19,8 juta. Pangsa pasar utama ekspor ikan kerapu 90\%dikirim ke Hongkong, sisanya ke Cina, Taiwan, Jepang, Korea Selatan, Vietnam, Thailand, Filipina, USA, Australia, Singapura, Malaysia, dan Perancis. Ikan kerapu sunu merupakan salah satu di antara jenis ikan kerapu yang cukup diminati dengan ciri khas berwarna merah. Ikan ini tersebar dari perairan Australia sampai kepulauan Jepang, dan Indonesia sebagai negara kepulauan memiliki potensi alami yg tinggi (Haemstra \& Randall, 1993). Laju eksploitasi ikan kerapu sunu pada kawasan tertentu di Indonesia, seperti perairan Kabupaten Kolaka, Sulawesi Tenggara, sudah di atas ambang batas lestari, dengan laju eksploitasi di atas 70\%(Landu et al., 2013). Eksploitasi berlebihan menyebabkan ikan ini mulai sulit diperoleh. Kegiatan budidaya merupakan salah satu upaya yang dapat memperbaiki ketimpangan laju eksploitasi di alam. Ketersediaan induk kerapu sunu yang siap memijah merupakan faktor penting untuk keberhasilan budidaya. Permasalahan utama dalam budidaya ikan kerapu sunu yang bersifat hermaprodit sekuensial yaitu keterlambatan perkembangan gonad dan perubahan kelamin dari betina menjadi jantan fungsional.

Seperti halnya vertebrata Iain, aktivitas reproduksi dan perubahan kelamin ikan diatur oleh aktivitas hormonal. Rangkaian stimulasi hormon diawali dengan pelepasan gonadotropin-releasing hormone $(\mathrm{GnRH})$ yang dihasilkan hypothal amus, yang merangsang sekresi dua jenis pituitary gonadotropins (GTHs), yaitu folliclestimulating hormone (FSH) dan luteinizing hormone (LH). FSH dan LH bekerja pada gonad untuk menghasilkan steroid seks yang mengatur perkembangan gonad. Selama proses perkembangan gonad, FSH disinyalir berperan untuk mengatur fase awal gametogenesis, seperti vitellogenesis pada betina dan spermatogenesis pada jantan, dan LH pada fase berikutnya dari gameto-genesis, seperti pematangan oocyte dan ovulasi pada betina dan spermiasi dan produksi semen pada jantan (Devlin et al., 2002; Hayakawa et al., 2008).

Oodev merupakan kombinasi PMSG (Pregnant Mare's Serum Gonadotropin) dan anti dopamin. PMSG atau eCG (Equine Chorionic Gonadotropin) merupakan glikoprotein yang memiliki fungsi aksi biologis seperti LH dan FSH, namun dengan fungsi sebagai FSH yang lebih dominan (Hafez et al., 2000). Dopamin merupakan neurotransmitter yang mempunyai peranan penting dalam regulasi reproduksi pada vertebrata, terutama sebagai sinyal penghentian gonadotropin di tingkat hipofisis dan pelemahan aksi GnRH terhadap gonadotropin. Dopamin dapat dihambat menggunakan anti dopamin, sehingga diharapkan sekresi gonadotropin akan meningkat (Popesku et al., 2010). Oodev yang merupakan premiks PMSG dan anti dopamin cukup efektif untuk memacu perkembangan gonad induk betina pada ikan air tawar seperti ikan tor Tor soro (Farastuti et al., 2014) dan ikan lele (Nainggolan et al., 2014).

Aromatase merupakan enzim kompleks yang bertanggung jawab untuk mengonversi androgen menjadi estrogen yang merupakan modulator penting konsentrasi estradiol. Estradiol sangat penting dalam regulasi semua proses yang berkaitan dengan diferensiasi dan perkembangan ovarium (Reading \& Sullivan, 2011). Penghambatan terhadap aktivitas aromatase dapat dilakukan dengan pemberian senyawa aromatase inhibitor (Ankley et al., 2002). Penggunaan aromatase inhibitor (Al) pada ikan hermaprodit protogini seperti ikan kerapu Epinephelus merra, menunjukkan perkembangan betina menjadi jantan fungsional. Uji coba Al secara in vitro juga menyebabkan penekanan terhadap produksi estradiol dan merangsang produksi testosteron dan 11ketotestosteron pada fragmen ovarium betina matang (Bhandari et al., 2004).

Induksi dengan aromatase inhibitor diharapkan dapat mempercepat perubahan gonad ikan kerapu sunu dari betina menjadi jantan, sedangkan penggunaan oodev dapat mempercepat kematangan gonad. Penelitian ini bertujuan untuk mendapatkan dosis hormon aromatase inhibitor dan oodev yang tepat untuk memacu perubahan kelamin dan perkembangan gonad ikan kerapu sunu.

\section{BAHAN DAN METODE}

\section{Ikan Uji}

Ikan uji yang digunakan dalam penelitian ini adalah calon induk ikan kerapu sunu Plectropomus leopardus F-1 yang belum pernah matang gonad, yang sebelumnya dipelihara di karamba jaring apung (KJA). Bobot ratarata dari calon induk kerapu sunu yang digunakan adalah 2,3 $\pm 0,28 \mathrm{~kg}$ sebanyak 35 ekor. Ikan uji dipelihara dalam tiga bak pemeliharaan yang berukuran masingmasing $50 \mathrm{~m}^{3}$ dengan sistem air mengalir dengan pergantian air $300 \%$ per hari. Adaptasi terhadap perubahan lingkungan pemeliharaan dilakukan selama satu bulan sebelum perlakuan. Pakan yang diberikan berupa ikan rucah dan ditambah vitamin mix dengan dosis $5 \mathrm{~g} / \mathrm{kg}$ pakan, pakan diberikan satu kali sehari 
pada pagi hari secara ad libitum.

Hormon yang digunakan dalam penelitian ini adalah aromatase inhibitor imidazole (1,3-Diaza-2,4Cyclopentadiene) Sigma Chemical Co dan oodev yang merupakan produk komersial yang mengandung kombinasi PMSG (Pregnant Mare's Serum Gonadotropin), dan anti dopamin.

Penelitian dilakukan secara eksperimental menggunakan rancangan acak lengkap (RAL). Perlakuan induksi hormonal yang diaplikasikan adalah (A) aromatase inhibitor $1 \mathrm{mg} \mathrm{kg}^{-1} \mathrm{ikan},(0)$ oodev $1 \mathrm{~mL}$ $\mathrm{kg}^{-1} \mathrm{ikan}$, (AO1) aromatase inhibitor 0,1 $\mathrm{mg} \mathrm{kg}^{-1} \mathrm{ikan}$ + oodev $1 \mathrm{~mL} \mathrm{~kg}^{-1}$ ikan, (AO2) aromatase inhibitor $1 \mathrm{mg} \mathrm{kg}^{-1} \mathrm{ikan}+$ oodev $1 \mathrm{~mL} \mathrm{~kg}^{-1}$ ikan, dan (K) tanpa hormon (kontrol).

Penerapan hormon dilakukan melalui penyuntikan sesuai dosis yang telah ditentukan. Pada kontrol juga dilakukan penyuntikan terhadap hewan uji menggunakan plasebo. Penyuntikan hormon tiap perlakuan dilakukan terhadap tujuh ekor calon induk, sehingga individu calon induk digunakan sebagai ulangan. Untuk membedakan ikan antar perlakuan digunakan radio tagging. Sampling awal dilakukan dengan mengambil sampel darah ikan kerapu sunu dan gonad. Sampling dilakukan setiap dua minggu setelah penyuntikan dan dilakukan pengamatan terhadap profil hormon dalam darah. Penyuntikan susulan dilakukan setiap dua minggu sesaat setelah dilakukan pengambilan darah. Penyuntikan dilakukan sebanyak empat kali dalam kurun waktu delapan minggu. Pada akhir penelitian minggu ke-10 dilakukan pengambilan sampel gonad.

\section{Analisis Hormon}

\section{Konsentrasi Testosteron dan Estradiol}

Dalam penelitian ini parameter yang diukur dan dianalisis adalah konsentrasi testosteron dan estradiol dalam darah ikan kerapu sunu. Analisis kedua hormon tersebut dilakukan pada awal penelitian, minggu ke-2, 4, 6, dan minggu ke-8. Pengambilan darah sebanyak $1 \mathrm{~mL}$ tiap ekor calon induk kerapu sunu. Pada saat pengambilan darah, ikan dibius dengan 2-phenoxyethanol $50 \mathrm{mg} / \mathrm{L}$ melalui perendaman pada wadah styrofoam berukuran $1 \mathrm{~m} \times 0,4 \mathrm{~m} \times 0,4 \mathrm{~m}$ dengan volume air $10 \mathrm{~L}$. Pengambilan darah ikan kerapu sunu dilakukan pada arteri pangkal ekor menggunakan syringe bervolume 2,5 mL dengan Heparin. Selanjutnya darah didiamkan selama dua jam dan dilanjutkan dengan melakukan sentrifuse dengan kecepatan 5.000 rpm selama 15 menit. Plasma darah yang diperoleh disimpan pada freezer bersuhu $-20^{\circ} \mathrm{C}$ sampai analisis berikutnya. Pengukuran konsentrasi hormon dalam plasma dilakukan dengan menggunakan ELISA (Enzymelinked immunosorbent assay) kit estradiol dan testosteron.

\section{Profil Histologi Gonad}

Pengamatan perkembangan gonad secara seluler, dilakukan melalui pemotongan jaringan (histologi) organ gonad pada awal dan akhir penelitian, sehingga dapat menentukan jenis kelamin dan tingkat kematangan ikan kerapu sunu. Pengamatan histologi gonad mengacu kepada Ferreira (1995) dan Longenecker \& Langston (2016).

\section{Ekspresi Gen DMRT1 dan SOX3}

Pengamatan proses dan perubahan yang berkaitan dengan reproduksi dan perubahan kelamin selama penelitian, dilakukan analisis terhadap ekspresi gen dengan menggunakan pengkode target gen spsesifik reproduksi. Gen pengkode untuk analisis ekspresi gen reproduksi meliputi DMRT1 yang merupakan gen pengkode yang berperan dalam proses pembentukan sperma dan SOX3 yang merupakan gen yang terkait dalam proses pembentukan sel telur. Tahapan analisis ekspresi gen terkait gen reproduksi sesuai Haryanti et al. (2014), target gen spesifik mengikuti Shin et al. (2009) seperti tertera pada Tabel 1.

\section{Analisis Data}

Data pengaruh perlakuan terhadap konsentrasi testosteron dan estradiol, profil perkembangan gonad (histologi) dan kecenderungan perubahan genital (seksual) pada ikan kerapu sunu melalui ekspresi gen yang terkait dengan reproduksi dari masing-masing perlakuan dilakukan secara deskriptif. Sementara, jumlah induk yang mengalami perubahan seksual dianalisis dengan chi square yaitu analisis uji beda nyata untuk data kualitatif dan jika hasil yang berbeda nyata $(P<0,05)$, maka untuk menentukan perlakuan yang memberikan respons terbaik dilakukan pengujian odd ratio yaitu ukuran asosiasi peluang kejadian pada suatu percobaan yang dihitung berdasarkan perbandingan nilai terjadinya kejadian yang diharapkan dengan kejadian yang tidak diharapkan.

\section{HASIL DAN BAHASAN}

\section{Konsentrasi Estradiol dan Testosteron}

Berdasarkan hasil analisis menunjukkan bahwa konsentrasi estradiol $\left(E_{2}\right)$ pada perlakuan $\mathrm{AO1}$ (aromatase inhibitor $0,1 \mathrm{mg} \mathrm{kg}^{-1}$ ikan + oodev $1 \mathrm{~mL}$ $\mathrm{kg}^{-1} \mathrm{ikan}$ ) dan AO2 (aromatase inhibitor $1 \mathrm{mg} \mathrm{kg}^{-1} \mathrm{ikan}$ + oodev $1 \mathrm{~mL} \mathrm{~kg}^{-1}$ ikan) pada akhir penelitian tidak terdeteksi (sangat rendah), berbeda pada perlakuan A 
Tabel 1. Sekuen primer yang digunakan untuk analisis ekspresi gen yang terkait dengan reproduksi kerapu sunu P. leopardus dengan metode RT-qPCR

Table 1. Primary sequences used in the for analysis of gene expression related reproduction of coral trout grouper $\mathbf{P}$. leopardus with RT-qPCR method

\begin{tabular}{lc}
\hline \multicolumn{1}{c}{ Primer } & Sekuen (5'-3') \\
\hline \multirow{2}{*}{ DMRT1 } & $\mathrm{F}\left(5^{\prime}-\right.$ CCT CCT ATT ACA ACT TCT ACC - 3') \\
& $\mathrm{R}\left(5^{\prime}-\right.$ GAC AGG CGG CCA TCA CC - 3') \\
\hline \multirow{2}{*}{ SOX3 } & $\mathrm{F}\left(5^{\prime}-\right.$ AGT GTC AGC GAC CAG GAG CG - 3') \\
& $\mathrm{R}\left(5^{\prime}-\right.$ TTT CCA GTC AGC CCC GAG C - 3') \\
\hline$\beta$-actin/internal kontrol & $\mathrm{F}\left(5^{\prime}-\right.$ GCA AGA GAG GTA TCC TGA CC - 3') \\
$\beta$-actin/internal control & $R\left(5^{\prime}-\right.$ CTC AGC TCG TTG TAG AAG G - 3') \\
\hline
\end{tabular}

(aromatase inhibitor $1 \mathrm{mg} \mathrm{kg}^{-1}$ ikan) dan 0 (oodev 1 $\mathrm{mL} \mathrm{kg}^{-1} \mathrm{ikan}$ ) yang sangat tinggi yaitu masing-masing 12,859 dan $9,037 \mathrm{ng} / \mathrm{mL}$. Konsentrasi testosteron (T) menunjukkan bahwa perlakuan AO2 memberikan konsentrasi yang lebih tinggi dibanding yang lain yakni 2,819 $\mathrm{ng} / \mathrm{mL}$. Konsentrasi $\mathrm{E}_{2}$ dan $\mathrm{T}$ setelah perlakuan dapat dilihat pada Tabel 2.

Penurunan konsentrasi $E_{2}$ yang diikuti dengan peningkatan konsentrasi T dalam plasma darah dapat menjadi indikator perubahan kelamin ikan kerapu sunu yang bersifat hermaprodit sekuensial protogini, yaitu perubahan terhadap fase jantan terjadi setelah melalui fase betina terlebih dahulu (Frisch, 2004). Terapi induksi hormonal yang dilakukan terhadap calon induk kerapu sunu memengaruhi konsentrasi hormon $\mathrm{E}_{2}$ maupun $\mathrm{T}$. Perlakuan AO2 (aromatase inhibitor 1 $\mathrm{mg} \mathrm{kg}^{-1} \mathrm{ikan}+$ oodev $1 \mathrm{~mL} \mathrm{~kg}^{-1}$ ikan) memiliki potensi untuk perubahan kelamin dari betina ke jantan yang lebih cepat, karena dapat meningkatkan kadar hormon T sebesar 2,8 kali dibandingkan kontrol. Konsentrasi hormon T pada perlakuan AO2 tersebut adalah 2,82 $\mathrm{ng} / \mathrm{mL}$; dan juga menunjukkan kadar $\mathrm{E}_{2}$ yang sangat rendah. Pada perlakuan lain, konsentrasi T tidak lebih tinggi dibanding kontrol 0,994 ng/mL. Konsentrasi T pada kontrol relatif cukup tinggi dan kemungkinan ikan sudah memasuki fase interseks secara alami. Observasi yang dilakukan Sembiring et al. (2013) menunjukkan konsentrasi $\mathrm{E}_{2}$ pada ikan kerapu sunu betina yang sudah matang gonad pada kisaran 0,55 $\mathrm{ng} / \mathrm{mL}$ sampai lebih dari $1 \mathrm{ng} / \mathrm{mL}$, sedangkan konsentrasi T dalam darah di atas $0,7 \mathrm{ng} / \mathrm{mL}$ dapat dipastikan ikan kerapu tersebut berkelamin jantan.

Efek pemberian aromatase inhibitor pada perlakuan A (aromatase inhibitor $1 \mathrm{mg} \mathrm{kg}^{-1-}$ ikan) tidak menunjukkan respons terhadap penurunan $\mathrm{E}_{2}$ maupun peningkatan konsentrasi $\mathrm{T}$, namun didapat setelah dikombinasikan dengan oodev yang memiliki fungsi biologis sebagai gonadotropin. Pemberian oodev tanpa Al pada perlakuan 0 (oodev $1 \mathrm{~mL} \mathrm{~kg}^{-1}$ ikan) dapat meningkatkan konsentrasi $\mathrm{E}_{2}$ lebih tinggi yaitu 9,04 $\mathrm{ng} / \mathrm{mL}$ dibanding kontrol 3,39 $\mathrm{ng} / \mathrm{mL}$. Pemberian oodev diharapkan dapat memacu perkembangan gonad baik jantan maupun betina karena merupakan gonadotropin exogenous dengan fungsi biologis sebagai FSH (fol-

Tabel 2. Konsentrasi estradiol dan testosteron dalam plasma darah kerapu sunu P. leopardus dengan induksi hormonal aromatase inhibitor dan oodev pada konsentrasi yang berbeda

Table 2. Estradiol and testoterone concentrations in blood plasma of coral trout grouper $\mathbf{P}$. leopardus with hormone induction of aromatase inhibitor and oodev with different concentrations

\begin{tabular}{lcc}
\hline & $\begin{array}{c}\text { Perlakuan } \\
\text { Treatments }\end{array}$ & \multicolumn{2}{c}{$\begin{array}{c}\text { Konsentrasi dalam darah } \\
\text { Concentration in blood }(\mathbf{n g} / \mathbf{m L})\end{array}$} \\
\cline { 2 - 3 } & Estradiol & Testosteron \\
\hline A & $12.859 \pm 3.06$ & $0.468 \pm 0.48$ \\
0 & $9.037 \pm 3.25$ & $0.569 \pm 0.01$ \\
A01 & 0 & $0.509 \pm 0.15$ \\
A02 & 0 & $2.819 \pm 2.23$ \\
Kontrol (Control) & 3.39 & $0.994 \pm 0.07$ \\
\hline
\end{tabular}


licle-stimulating hormone) yang dapat memacu perkembangan gonad jantan maupun betina (Hafez et al., 2000). Kombinasi Al dan oodev dengan dosis Al yang terlalu rendah $\left(0,1 \mathrm{mg} \mathrm{kg}^{-1}\right.$ ikan) juga kurang mampu memperkuat efek Al dalam meningkatkan konsentrasi T pada perlakuan A01 (aromatase inhibitor $0,1 \mathrm{mg} \mathrm{kg}^{-1} \mathrm{ikan}+$ oodev $1 \mathrm{~mL} \mathrm{~kg}^{-1}$ ikan). Al dapat menghambat sintesis $\mathrm{E}_{2}$ sehingga dapat meningkatkan konsentrsi $\mathrm{T}$ yang dapat mempercepat perubahan kelamin menjadi jantan. Namun, pada ikan kerapu sunu yang diuji menunjukkan penghambatan modulasi $\mathrm{E}_{2}$ tidak serta merta mengarah pada peningkatan $\mathrm{T}$, namun masih perlu induksi hormon gonadotropin eksternal untuk meningkatkan metabolisme gonad. Ikan kerapu sunu dalam kondisi budidaya cenderung mengalami gangguan perkembangan reproduksi, dikarenakan sinyal lingkungan untuk perkembangan reproduksi secara alami cenderung tidak diperoleh dalam wadah budidaya. Perkembangan gonad/gametogenesis (spermatogenesis dan vitellogenesis) dan pematangan akhir (spermiasi dan pematangan oosit) diatur oleh axis otak-pituitary-gonad, yaitu rangsangan lingkungan akan direspons oleh otak melalui pelepasan GnRH (gonadotropin-releasing hormon) yang direspons oleh pituitary dengan sekresi gonadotropin FSH (folliclestimulating hormone) dan LH (luteinizing hormone) ke sistem sirkulasi menuju gonad dan merangsang sintesis hormon steroid kelamin yang merupakan modulator perkembangan gonad (Mylonas et al., 2010).

\section{Profil Histologi Gonad Kerapu Sunu P. leopardus}

Hasil histologi gonad menunjukkan bahwa tahap perkembangan ikan kerapu sunu terdiri atas fase betina, fase interseks dan fase jantan. Pada gonad betina, tingkat perkembangan gonad menunjukkan variasi oosit mulai dari tingkat satu hingga tiga. Pada gonad interseks, terdapat oosit stadia awal dan testis sudah mulai berkembang lebih dari 50\%nya. Pada gonad jantan, sudah didominasi pertumbuhan testis. Hasil histologi gonad dapat dilihat pada Gambar 1. Perkembangan gonad dan proporsi perubahan kelamin ditabulasi pada Tabel 3.

Berdasarkan hasil pengamatan menunjukkan bahwa induksi hormon aromatase inhibitor dan oodev pada perlakuan $\mathrm{O}$ dan $\mathrm{AO2}$ memberikan dampak terhadap perubahan gonad menjadi jantan dengan proporsi masing-masing 50\% dan 100\% Sementara itu, pada kontrol serta perlakuan A dan AO1 hanya memberikan dampak perubahan peralihan gonad betina menjadi jantan (intersex) dengan proporsi yang sama yaitu masing-masing $50 \%$

Tabel 3. Perkembangan gonad calon induk kerapu sunu P. leopardus dengan induksi hormon aromatase inhibitor dan oodev pada konsentrasi yang berbeda

Table 3. Gonadal development of coral trout grouper P. leopardus induced by hormone aromatase inhibitor and oodev with different concentrations

\begin{tabular}{|c|c|c|c|c|c|c|c|c|}
\hline \multirow{2}{*}{$\begin{array}{l}\text { Perlakuan } \\
\text { Treatments }\end{array}$} & \multirow{2}{*}{$\begin{array}{l}\text { Bobot } \\
\text { Weight }\end{array}$} & \multirow{2}{*}{$\begin{array}{l}\text { Jenis gonad } \\
\text { Genital type }\end{array}$} & \multirow{2}{*}{$\begin{array}{c}\text { Stadia } \\
\text { kematangan gonad } \\
\text { Gonad maturation } \\
\text { stage }\end{array}$} & \multicolumn{3}{|c|}{$\begin{array}{c}\text { Jumlah induk } \\
\text { berdasarkan jenis kelamin } \\
\text { Number of broodstock by sex }\end{array}$} & \multicolumn{2}{|c|}{$\begin{array}{l}\text { Odds rasio } \\
\text { Odds ratio }\end{array}$} \\
\hline & & & & $\begin{array}{l}\text { Betina } \\
\text { Female }\end{array}$ & $\begin{array}{l}\text { Interseks } \\
\text { Intersex }\end{array}$ & $\begin{array}{c}\text { Jantan } \\
\text { Male }\end{array}$ & $\begin{array}{c}\text { Jantan } \\
\text { Male }\end{array}$ & $\begin{array}{l}\text { Interseks } \\
\text { Intersex }\end{array}$ \\
\hline $\begin{array}{l}\text { Kontrol } \\
\text { Control }\end{array}$ & 2.08 & $\begin{array}{c}\text { Betina (Female) } \\
\text { Interseks (Intersex) }\end{array}$ & $\begin{array}{c}\text { Stadia 1, 2, } 3 \\
\text { Interseks akhir }\end{array}$ & 1 & 1 & 0 & 0 & 1 \\
\hline A & 2.41 & $\begin{array}{c}\text { Interseks (Intersex ) } \\
\text { Betina (Female) }\end{array}$ & $\begin{array}{l}\text { Interseks akhir, } \\
\text { banyak spermatid } \\
\text { Stadia 1, } 2\end{array}$ & 1 & 1 & 0 & 0 & 1 \\
\hline 0 & 2.57 & $\begin{array}{l}\text { Betina (Female) } \\
\text { Jantan (Male) }\end{array}$ & $\begin{array}{c}\text { Stadia 1, 2, } 3 \\
\text { Spermatid }\end{array}$ & 1 & 0 & 1 & 1 & 0 \\
\hline AO1 & 2.5 & $\begin{array}{c}\text { Betina (Female) } \\
\text { Interseks (Intersex) }\end{array}$ & $\begin{array}{c}\text { Stadia 1, 2, } 3 \\
\text { Interseks akhir }\end{array}$ & 1 & 1 & 0 & 0 & 1 \\
\hline $\mathrm{AO} 2$ & 2.42 & $\begin{array}{l}\text { Jantan (Male) } \\
\text { Jantan (Male) }\end{array}$ & $\begin{array}{c}\text { Spermatid } \\
\text { Spermatozoa }\end{array}$ & 0 & 0 & 2 & $\infty$ & 0 \\
\hline
\end{tabular}

Keterangan: $\infty$ menunjukkan nilai odd ratio pengaruh perlakuan dengan proporsi jantan $100 \%$ 


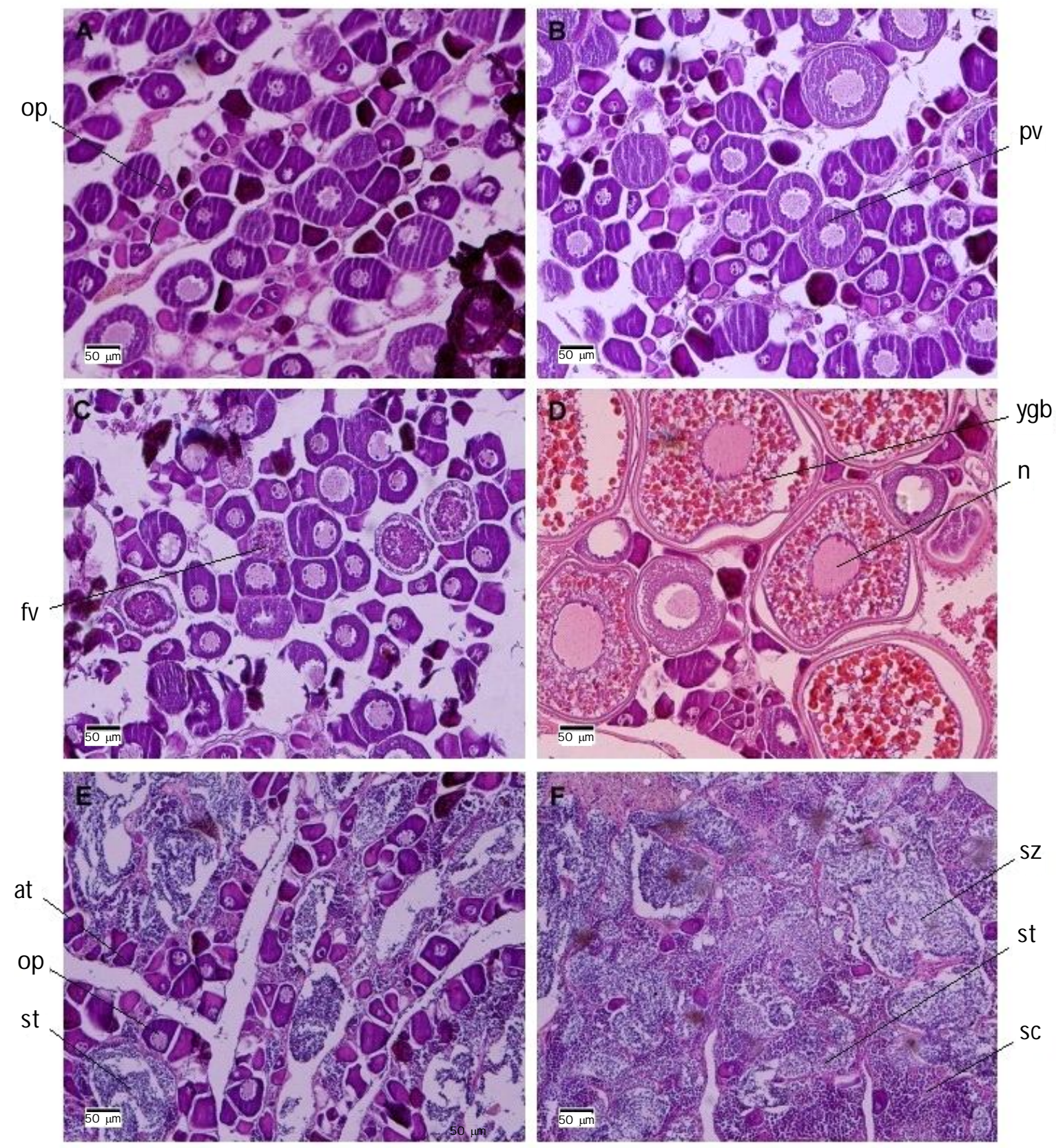

Gambar 1. Histologi gonad ikan kerapu sunu P. leopardus dengan induksi hormon aromatase inhibitor dan oodev (A. stadia kematangan oocyte tingkat 1; 0ocyte primer (op); B. stadia kematangan oocyte tingkat-2; previtelogenic (pv); C. stadia kematangan oocyte tingkat-3; fase pertengahan folikel vitelogenin (fv); D. stadia kematangan oocyte tingkat-4; nucleus (n), yolksac globule (y.gb); E. gonad Interseks; spermatid (st), oocyte primer (op), atresia (at); F. jantan; spermatid (st), spematocyte (sc), spermatozoa (sz)).

Figure 1. Gonadal histology of coral trout gropers P. leopardus treated with hormone induction of aromatase inhibitor and oodev using different concentrations (A. oocyte stage-1; primary oocyte (op); B. oocyte stage-II; previtelogenic (pv); C. oocyte stage-III; fase pertengahan folikel vitelogenin (fv); D. oocyte stageIV; nucleus (n), yolksac globule $(y . g b) ; E$. intersex gonad; spermatid (st), primeryoocyte (op), atresia (at); F. male; spermatid (st), spematocyte (sc), spermatozoa (sz)). 
Berdasarkan analisis chi square menunjukkan bahwa tidak ada perbedaan nyata $(P>0,05)$. Namun demikian, ada kecenderungan bahwa peluang perubahan menjadi jantan pada perlakuan A02 lebih besar daripada perlakuan yang lain yaitu $\infty$ kali; sementara itu, pada perlakuan 0 memberikan peluang perubahan sebesar satu kali. Pada perlakuan kontrol, A dan AO1 memberikan peluang perubahan gonad interseks sebesar masing-masing satu kali.

Hasil analisis histologi gonad calon induk kerapu sunu menunjukkan perkembangan gonad ikan kerapu sunu memiliki tahapan perkembangan sel yang berbeda atau asynchronous. Ikan kerapu sunu bersifat multiplespawner atau memijah beberapa kali pada musim pemijahan (Ferreira, 1995). Beberapa ikan kemungkinan sudah mulai berubah menjadi jantan secara alami. Ikan kerapu sunu yang digunakan dalam penelitian ini merupakan calon induk kerapu sunu yang belum pernah matang gonad walaupun secara ukuran seharusnya sudah memijah. Sembiring et al. (2013), menyatakan adanya ikan kerapu sunu yang berukuran $1 \mathrm{~kg}$ sudah matang gonad dan ukuran $2 \mathrm{~kg}$ sudah ada yang berubah menjadi jantan fungsional. Perubahan kelamin jantan diperoleh pada perlakuan $\mathrm{AO} 2$ (aromatase inhibitor $1 \mathrm{mg} \mathrm{kg}^{-1}$ ikan + oodev $1 \mathrm{~mL} \mathrm{~kg}$. ${ }^{1} \mathrm{ikan}$ ) dengan proporsi $100 \%$ jantan dengan nilai odd ratio tak terhingga $(\infty)$. Sementara itu perubahan menjadi jantan juga terjadi pada perlakuan 0 yaitu pemberian oodev $1 \mathrm{~mL} \mathrm{~kg}^{-1}$ ikan dengan peluang sebesar satu dengan proporsi perubahan $50 \%$ Sementara itu, pada perlakuan yang lain baik kontrol, $A$, maupun AO1 perubahan kelamin hanya mencapai pada stadia interseks (peralihan betina menjadi jantan). Pemberian oodev $1 \mathrm{~mL} \mathrm{~kg}^{-1}$ dapat memacu perkembangan gonad ikan kerapu yang memasuki fase interseks berubah menjadi jantan. Peranan oodev lebih kepada fungsi sebagai FSH yang fungsi utamanya memacu perkembangan gonad, baik spermatogenesis maupun oogenesis, dapat diaplikasikan baik pada ikan jantan atapun betina. Menurut Akbar et al. (2015), oodev efektif untuk meningkatkan produksi sperma pada udang vaname. Ikan kerapu sunu yang sudah mulai berubah menjadi jantan, juga potensial untuk dipacu menggunakan oodev agar dapat segera matang gonad dan fungsional menghasilkan sperma.

\section{Ekspresi Gen yang Terkait dengan Reproduksi}

Ekspresi gen yang terkait dengan reproduksi pada kerapu sunu P. leopardus, diamati dalam penelitian ini dengan menggunakan target gen DMRT1 dan SOX3 untuk mengekspresikan profil gonad ikan kerapu sunu. Kelipatan ekspresi gen terkait reproduksi pada kerapu sunu yang diinduksi hormon aromatase inhibitor dan oodev dengan konsentrasi berbeda dapat dilihat pada Gambar 2.

Pada analisis ekspresi untuk target gen DMRT1 (spermatogenesis) menunjukkan kelipatan pola ekspresi yang rendah. Pada kontrol (tanpa induksi hormon) terjadi kelipatan ekspresi gen DMRT1 sebesar 1,39 kali, sedangkan pada perlakuan A, 0, dan A01 kelipatan ekspresi masing-masing sebesar 1,33; 0,89; dan 0,14 kali. Hal yang berbeda terlihat pada perlakuan $\mathrm{AO} 2$ yang menunjukkan ekspresi gen spermatogenesis tinggi, yaitu 5,62 kali.

Ekspresi gen terkait reproduksi yang ditunjukkan dengan target gen SOX3 (vitellogenesis) terlihat adanya peningkatan kelipatan ekspresi pada semua perlakuan induksi hormon dibandingkan kontrol. Kelipatan ekspresi dari target gen SOX3 pada kontrol sebesar 1,38 kali; sedangkan pada perlakuan A dan 0 masingmasing sebesar 7,20 dan 7,17 kali. Pada perlakuan A01 hanya diperoleh kelipatan ekspresi 3,15 kali dan 8,75 kali pada perlakuan A02.

Pengamatan secara molekular perkembangan gonad dan perubahan kelamin ikan kerapu sunu yang diberi perlakuan hormon, dilakukan terhadap ekspresi gen-gen yang terkait reproduksi jantan dan betina, yaitu DM RT1 yang memiliki peranan dalam spermatogenesis, Sox3 yang terkait dengan vitellogenesis. Nilai ekspresi gen DMRT1 pada perlakuan A02, ikan yang sudah berubah menjadi jantan, menunjukkan kecenderungan peningkatan nilai ekspresi yang tinggi dibanding perlakuan lain maupun kontrol, yaitu masing-masing 5,63. Pada ekspresi gen SOX3 yang terkait oogenesis, nilai ekspresi cenderung merata dengan nilai ekspresi tertinggi pada perlakuan $\mathrm{AO2}$ yang sudah berubah menjadi jantan, sedangkan pada kontrol dan perlakuan AO1 jauh lebih rendah. Nilai ekspresi DMRT1 terekspresi di semua perlakuan karena terdapat ikan yang mulai berubah mejadi jantan secara alami. M enurut Xia et al. (2007), DM RT1 hanya terekspresi pada saat gonad mulai berubah menjadi testis dan tidak terekspresi pada gonad betina Epinephelus coioides. SOX3 terekspresi pada proses vitellogenesis, namun pada perlakuan $\mathrm{AO} 2$ yang sepenuhnya jantan SOX3 terekspresi lebih tinggi dibanding perlakuan lain. Nampaknya, induksi hormon pada ikan kerapu sunu dapat mengekspresikan peran gen DMRT1 dan SOX3 sebagai pengkode dalam perkembangan dan pematangan gonad jantan. Hal ini sesuai dengan peranan DMRT1 dan SOX3 pada black porgy Acanthopagrus schlegeli yang menunjukkan ekspresi maksimal pada gonad jantan yang mulai matang (Shin et al., 2009). 


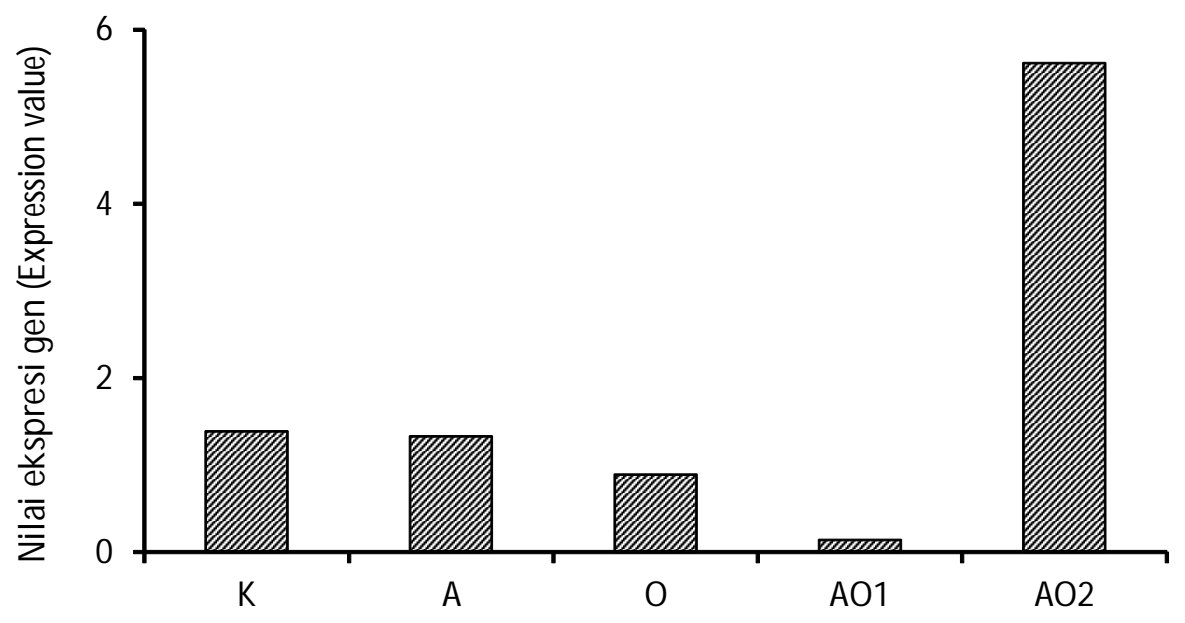

Perlakuan (Treatments)

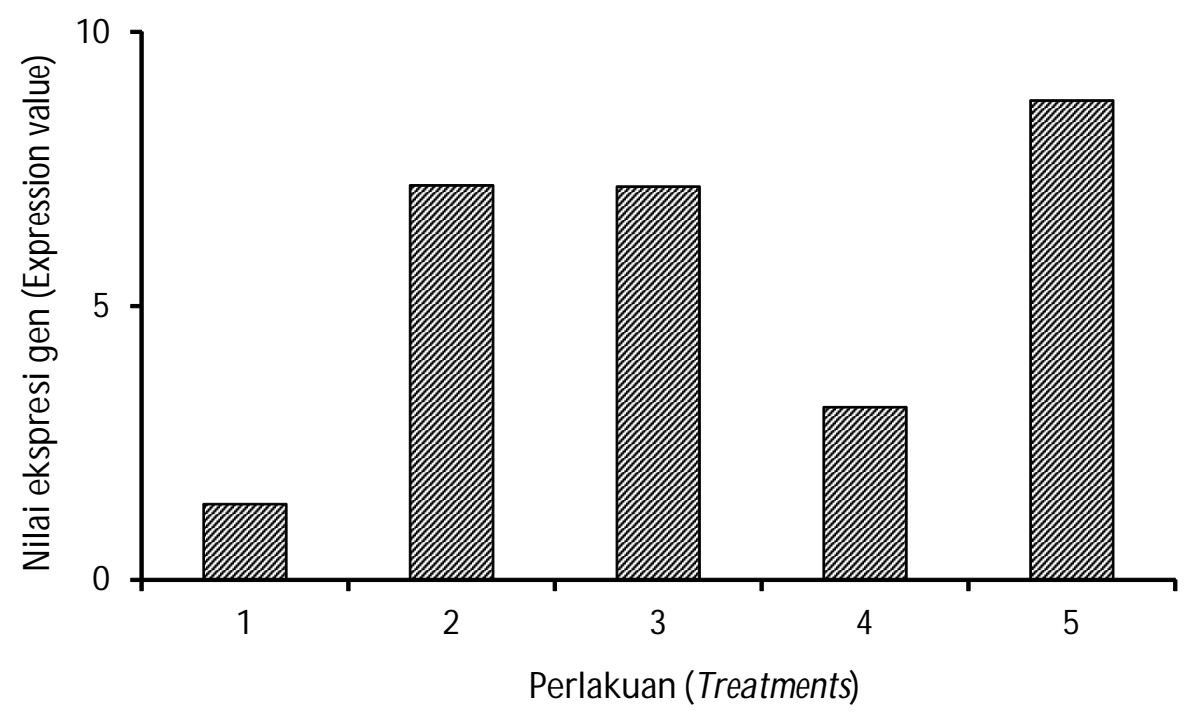

Gambar 2. Tingkat ekspresi mRNA dari gen yang terkait reproduksi (A) DMRT1 dan (B) SOX3 ikan kerapu sunu P. leopardus dengan induksi hormon aromatase inhibitor dan oodev pada konsentrasi yang berbeda.

Figure 2. Expression value of mRNA from reproduction related genes (A) DMRT1 and (B) SOX3 of coral trout grouper, $\mathbf{P}$. leopardus, treated with hormone induction of aromatase inhibitor and oodev using different concentrations.

Induksi hormonal dengan kombinasi Al dan oodev dengan dosis yang tepat terbukti mampu secara efektif dan efisien menginduksi proses perubahan kelamin dari betina menjadi jantan pada calon induk kerapu sunu. Pengaruh terapi hormonal ini telah mempercepat perubahan kelamin betina menjadi jantan dengan tingkat kematangan gonad yang memasuki fase matang gonad. Hal ini terlihat dari hasil histologi yang menunjukkan dihasilkannya spermato zoa dalam gonad.

\section{KESIMPULAN}

Induksi hormonal menggunakan kombinasi Aromatase Inhibitor $1 \mathrm{mg} \mathrm{kg}^{-1}$ ikan + Oodev $1 \mathrm{~mL}$ $\mathrm{kg}^{-1}$ ikan efektif dalam proses pembentukan profil kelamin jantan dan memacu perkembangan gonad pada ikan kerapu sunu Plectropomus leopardus. Efek terapi hormonal mempercepat kematangan gonad dengan terbentuknya spermatozoa. Induksi oodev $1 \mathrm{~mL} \mathrm{~kg}^{-1}$ ikan dapat mempercepat perubahan menjadi jantan pada ikan yang memasuki fase interseks.

\section{UCAPAN TERIMA KASIH}

Penelitian ini dilaksanakan dengan dukungan pendanaan dari DIPA 2014 Balai Besar Riset Budidaya Laut dan Penguluhan Perikanan Gondol, Kementerian Kelautan dan Perikanan. Terima kasih disampaikan kepada staf teknisi litkayasa dan peneliti Balai Besar 
Riset Budidaya Laut dan Penyuluhan Perikanan, Gondol, Bali yang telah banyak membantu selama pelaksanaan penelitian.

\section{DAFTAR ACUAN}

Akbar, F., Sudrajat, A.O., \& Subaidah, S. (2015). Kualitas sperma induk Litopenaeus vannamei yang disuntik PMSG dan antidopamin. Jurnal Akuakultur Indonesia, 14(2), 98-103.

Ankley, G.T., Kahl, M.D., Jensen, K.M., Hornung, M.W., Korte, J.J., Makynen, E.A., \& Leino, R.L. (2002). Evaluation of the aromatase inhibitor Fadrozole in a short-term reproduction assay with the fatted minnow (Pimephales promelas). Toxicological Sciences, 67, 121-130.

Bhandari, R.M., Higa, M., Nakamura, S., \& Nakamura, M. (2004). Aromatase inhibitor induces complete sex change in the protogynous honeycomb grouper (Epinephelus merra). Molecular Reproduction and Development Journa, I(67), 303-307.

Devlin, R.H., \& Nagahama, Y. (2002). Review article: sex determination and sex differentiation in fish: an overview of genetic, physiological, and environmental influences. Aquaculture, 208, 191-364.

Farastuti, E.R., Sudrajat, A.O., \& Gustiano, R. (2014). Induksi ovulasi dan pemijahan ikan soro (Tor soro) menggunakan kombinasi hormon. Limnotek, 21(1), 87-94.

Ferreira, B.P. (1995). Reproduction of the common coral trout Plectropomus leopardus from the central and northern Great Barrier Reef. Bulletin of Marine Science, 56(2), 653-669.

Frisch, A. (2004). Sex-change and gonadal steroids in sequentially-hermaphroditic teleost fish. Reviews in Fish Biology and Fisheries, 14, 481-499.

Haemstra, P.C., \& Randal, J.E. (1993). Groupers of the World. FAO Species Catalogue, 16, 292-293.

Haryanti, Muzaki, A., Sembiring, S.B.M., Fahrudin, Permana, I G.N., \& Wardana, I K. (2014). The effect of probiotic on immunity improvement in the fry and spawner production of pacific white shrimp Litopenaeus vannamei. Indonesian Aquaculture Journal, 9(2), 133-146.

Hayakawa, Y., Morita, T., Kitamura, W., Kanda, S., Banba, A., Nagaya, H., Hotta, K., \& Sohn, Y.C.
(2008). Biological activities of single-chain goldfish follicle-stimulating hormon and luteinizing hormone. Aquaculture, 274, 408-415.

Hafez, E.S.E., Jainudeen, M.R., \& Rosnina, Y. (2000). Hormones, growth factors, and reproduction. 7th Ed. Maryland: Lippincott Williams \& Wilkins. Reproduction in farm animals, p. 33-54.

Landu, A., \& Asni. (2014). Penanggulangan dampak ilegal fishing ikan kerapu sunu Plectropomus leopardus di perairan Kabupaten Kolaka. Phinisi, 10(1), 19-23.

Longenecker, K., \& Langston, R. (2016). The Jungle Histology Atlas of Gonad Stages in Coral-Reef Fishes. Pacific Biological Survey. Hawaii (US), Bishop Museum.

Mylonas, C.C., Fostier, A., \& Zanuy, S. (2010). Broodstock management and hormonal manipulations of fish reproduction. General and Comparative Endocrinology, 165,516-534.

Nainggolan, A., Sudrajat, A.O., Utomo, B.Y., \& Harris, E. (2014). Ovarian maturation inasian catfish (Clarias sp.) by combination oodev and nutrition addition Spirulina plantesis. IJSBAR, 15(1), 54-58.

Popesku, J.T., Martyniuk, C.J., Denslow, N.D., \& Trudeau, V.L. (2010). Rapid dopaminergic modulation of the fish hypothalamic transcriptome and proteome. Plos One, 5(8), el2338.

Reading, B.J., \& Sullivan, C.V. (2011). The reproductive organs and process: Vitellogenesis in fishes. Encyclopedia of Fish Physiology, 635-646.

Sembiring, S.B.M., Priyono, A., Hutapea, J.H., \& Setiadharma, T. (2013). Determinasi jenis kelamin ikan kerapu sunu (Plectropomus leopardus) dengan uji serologi. Jurnal Riset Akuakultur, 8(2), 181-189.

Shin, H.S., An, K.W., Park, M.S., Jeong, M.H., \& Choi, C.Y. (2009). Quantitative mRNA expression of sox3 and DMRT1 during sex reversal, and expression profile after GnRHa administration in black porgy, Acanthopagrus schlegeli. Comparative Biochemistry and Physiology Part B, 154, 150-156.

Xia, W., Zhou, L., Yao, B., Li, C.J., \& Gui, J.F. (2007). Differential and spermatogenic cell-spesific expression of DMRT1 during sex reversal in protogynous hermaphroditic groupers. Molecular and Cellular Endocrinology, 263, 156-172. 